houdingen van tijd wordt zeer uitvoerig behandeld. In het betrokken hoofdstuk ,Das Zeitproblem in der Produktion" blijkt nog eens duidelijk, dat zonder kennis van samengestelde interest het tot de bedrijfseconomie behorende afschrijvingsprobleem niet behoorlijk bestudeerd kan worden.

Tot de belangrijkste grondslagen is ongetwijfeld mede te rekenen de in dit tweede deel behandelde uitwerking van Hicks" "marginal rate of substitution" (zie J. R. Hicks, Value and Capital, An inquiry into some fundamental principles of economic theory, Oxford 1939), welke - ik ben dit met de schrijver eens - in de plaats dient te komen van het onmeetbare grensnut. De eerste Gossense wet is „ohne Bedeutung für die theoretische Analyse... Demgegenüber hat eine Theorie, die auf dem Gesetz der abnehmenden Grenzrate der Substitution aufbaut, zwei entscheidende Vorzüge: Sie setzt nur das voraus, was zu ihrem Aufbau wirklich vorausgesetzt werden musz, nicht mehr; und sie geht nicht von unbeweisbaren Annahmen, sondern von einer empirischen Grundlage aus" (blz. 117). In embryonaire toestand was deze gedachte m.i. bij Pareto (Manuel d'économie politique) en Cassel (Gustav Cassel, Theoretische Sozialökonomie) reeds aanwezig.

De hoofdstukken over de elasticiteit van de vraag in het derde deel en de prijsleer in het vierde deel (marktvormen) kan ik eenieder ter lezing aanbevelen (blz. 156-256). In deze bladzijden worden de overeenkomstige prestaties van Eucken kwalitatief belangrijk overtroffen. De leer van Von Stackelberg is zuiver en helder, die van Eucken bevat meerdere belangrijke fouten. Het belangrijkste verschil zit in het feit, dat Eucken de .monopolistische concurrentie in enge zin" uit de tweede helft van het boek van Chamberlin niet kent. Ten opzichte van ,Marktform und Gleichgewicht" betekent zijn ",Grundlagen" een belangrijke vooruitgang, omdat hij in dit laatste werk veel realistischer is en duidelijk aangeeft, dat de prijsvaststelling primair is en dat de hoeveelheid zich aanpast (blz. 252). De gedachte van de gelijkwaardigheid van prijs- en hoeveelheidspolitiek heeft hij verlaten. Het is nuttig de in deze bladzijden door Von Stackelberg ontwikkelde theorie te vergelijken met de corresponderende hoofdstukken van Chamberlin, Triffin, Meyers, Garver and Hansen, Eucken en vele anderen. Dit zij verder aan de lezer zelf overgelaten.

Onder de lijst van tijdschriften (blz. 354/5) bevinden zich wèl Deense, Zweedse, Zwitserse, Italiaanse, Spaanse, enz., maar geen Nederlandse tijdschriften.

De literatuurlijst is een juweeltje. Van vele courante werken, die wij regelmatig in het Engels lezen, blijken Duitse vertalingen te bestaan.

In Nederland is in de jongste tijd veel geschreven over het object der bedrijfseconomie. Het lijkt mij in verband met de recente ontwikkeling der prijsleer vóór alles noodzakelijk zich te bezinnen op de grondslagen der kostprijsleer en haar aansluiting op de algemene economie.

\title{
DE FUNCTIE VAN DE INTERNE ACCOUNTANT (slot)
}

door Mr B. Moret

\section{Verhouding tussen interne en externe accountant.}

Ik kom dan nu tot het onderwerp, dat bij iedere bespreking van de functie van de interne accountant steeds het kernpunt uitmaakt. Naar mijn mening kan men niet spreken over de verhouding tussen de interne en

m a b blz. 37 
externe accountant, zonder hierin te betrekken de verhouding van de externe accountant tot de interne controle in het algemeen. De interne accountant is een verbijzonderde vorm van de interne contrôle in het algemeen. Voor de onderneming èn voor de externe accountant is het wel van belang, wie met een bepaald gedeelte van de interne contrōle belast is. En het feit, dat de interne contrōleur lid van het N.I.V.A. is en als zodanig gebonden is aan bepaalde regels, zoals het Reglement van Arbeid en het Reglement op de Tuchtrechtspraak, geeft waarborgen zowel wat betreft deskundigheid als wat betreft taakvervulling aan degenen, met wie hij tot samenwerking geroepen is. Dr. A. Mey ${ }^{11}$ ) acht een principieel verschil aanwezig tussen het geval, dat de openbare accountant steunt op interne contrōle en het geval, dat deze samenwerkt met een interne accountant in een groot bedrijf. Hij ziet in de laatstgenoemde een vorm van "gesuperponeerde interne contrôle", die tegenover de bedrijfsleiding een overeenkomstige betekenis heeft als de openbare accountant tegenover het publiek. Ik kan dit verschil niet als van principiële betekenis zien en beschouw de interne accountant als een geperfectioneerde vorm van de interne contrôle in het algemeen.

Indien wij het vraagstuk van de verhouding tussen interne en externe accountant op de juiste manier willen benaderen, moeten wij dit aanvatten van de kant van de externe accountant, omdat deze de hogere verantwoordelijkheid - mogen de interne accountants, die dit lezen, mij vergeven - heeft. Uit deze opmerking blijkt, dat ik bij de verhouding tussen de interne en de externe accountant uitsluitend denk aan het geval, dat aan deze laatste de contrōle van de jaarrekening is opgedragen en het er nu om gaat, in hoeverre hij de interne accountant bij deze contröle kan en mag inschakelen. De openbare accountant is in dit geval de vertrouwensman van de gemeenschap: hierdoor ontstijgt hij aan de kring van zijn opdrachtgevers en leidt zijn verantwoordelijkheid en zijn taak niet van hen af, maar van het vertrouwen, dat het maatschappelijk verkeer stelt in zijn deskundigheid en onafhankelijkheid: de interne accountant is een orgaan van de onderneming: hij voert slechts de door de ondernemingsleiding gedelegeerde contrôle uit: zijn bevoegdheid overschrijdt niet de grenzen, hem door het beheer gesteld, al zal het beheer hem, als vakman, de uitvoering van zijn taak overlaten; en zijn verantwoordelijkheid reikt niet verder dan die van elk ander contrôle-orgaan in de onderneming, hetgeen wil zeggen, dat hij slechts tegenover de bedrijfsleiding, die hem een deel van haar bevoegdheden heeft overgedragen, zich behoeft te verantwoorden. Daar de functie van de openbare accountant in dit geval een wijdere strekking heeft en zijn verantwoordelijkheid een grotere is, zal hij de leiding moeten geven op het gebied, waar de werkzaamheden van de interne en de externe accountant samenvallen.

Als uitgangspunt voor mijn beschouwing zou ik daarom willen nemen de eis voor eigen actie van de public accountant om tot certificering van de jaarrekening te mogen komen. Dr. Sternheim ${ }^{12}$ ) drukt het als volgt uit: „Het doel der accountantscontrỏle is in het algemeen de vaststelling der juistheid van de administratieve verantwoording op andere wijze dan die, welke uit de bestaande administratie zelve kan voorkomen. Het is geen aanvullende contrôle, het is een zelfstandige naar eigen aard zich regelende actie tegenover het gevoerde beheer". Prof. Limperg drukt het

11) Dr. A. Mey, Accountantsdag 1936 .De Accountant" 1936 pagina 245 en 327.

12) Dr. A. Sternheim: „De Accountantscontrôle”, Delwel, Wassenaar 1924.

m a b blz. 38 
iets anders uit in zijn M.A.B. artikelen: ${ }^{13}$ ) „,De accountants-vertrouwensman ontleent zijn algemene functie in het verkeer aan de behoefte aan deskundige en onafhankelijke contröle en de behoefte aan een op die' contrōle gegrond deskundig en onafhankelijk oordeel. Ook hieruit spreekt duidelijk de eis, dat de accountant zijn contrôlewerk zelfstandig, onafhankelijk en los van de bestaande organisatie van de onderneming verricht.

Het is niet mijn bedoeling verder in te gaan op de vraag, aan welke eisen de contrôle, ten behoeve van het maatschappelijk verkeer door de externe accountant, moet voldoen. Ik laat hiermede dus alle beschouwingen over het verantwoordelijkheidsvraagstuk van de openbare accountant weg.

Wanneer wij nu de vraag onder het oog zien, in hoeverre de openbare accountant bij zijn werk van de interne contrôle-organisatie van de onderneming gebruik kan en moet maken, dan kunnen wij hier twee standpunten onderscheiden.

Het eerste standpunt bepaalt, dat de externe accountant het gehele contrôlewerk zẹlf moet verrichten; een verzachting hierop wordt gevonden in de toevoeging, dat men, met bepaalde beperkingen, van de interne contrôle-organisatie in de onderneming mag gebruik maken voor accuratesse- en detailcontrōle, onder voorwaarde, dat de betreffende handelingen omspannen worden door een door de externe accountant uit te oefenen totalencontrôle.

Het andere standpunt stelt, dat de externe accountant onvoldoende deskundig en door het repressieve karakter van zijn contrôle ook niet in staat is om de taak van de interne contrôle geheel te vervullen: hij kan niet alle primaire bedrijfshandelingen zelfstandig en volledig onderzoeken en dus is een volledige eigen actie van de openbare accountant onmogelijk. Tegen deze bewering merken de aanhangers van het eerste standpunt op, dat, zo dit alzo moge zijn, de oplossing daarin gevonden moet worden, dat de gehele interne contrôledienst uitsluitend ondergeschikt moet worden gemaakt aan de openbare accountant.

Beide opvattingen willen dus van de interne contrőle gebruik maken. In de practische uitwerking is echter nog een heel belangrijk verschil tussen de verschillende groepen over de mate, waarin men van de interne controle gebruik wil maken: ik wil hierover straks nog wat meer zeggen. Beide standpunten beroepen zich op het economisch principe bij de vraag omtrent de inschakeling van de interne contrôle: dit is echter een vaag begrip en scherpe onderscheiding is hier nodig. Zeer verhelderend werken in dit verband de hiernavolgende opmerkingen van Prof. Dr. S. Kleerekooper in zijn artikel over "De Steekproeven als middel van Accountantscontrôle in de Litteratuur". ${ }^{14}$ )

$\mathrm{Om}$ antwoord te kunnen geven op de vraag of de accountant een deel van de resultaten van de interne contröle kan overnemen, wanneer hij zich door steekproeven overtuigt, dat het stelsel van de interne contrōle behoorlijk gewerkt heeft, zou men, volgens de heer Kleerekooper, het volgende moeten weten:

1. Wat is het nut van een volledige differentiatie van de contrôle naar het accountantskantoor;

2. In welke gevallen zal dit nut in het algemeen de kosten van de differentiatie overtreffen;

13) Prof. Dr. Th. Limperg: "De Functie van den Accountant en de leer van het Gewekte Vertrouwen", M.A.B. October 1932.

$\left.{ }^{14}\right)$ Prof. Dr. S. Kleerekoper: „De Steekproeven als middel van Accountantscontrôle in de Litteratuur", M.A.B. Februari 1933.

m a b blz. 39 
3. In welk opzicht vermindert het nut, indien de differentiatie onvolkomen wordt door te steunen op de interne contrôle, d.w.z. door de resultaten van de interne contrôle zonder volledig onderzoek als juist te erkennen.

4. Zal er na een eventuele vermindering van het nut, geconstateerd sub. 3. toch nog een nutsaldo boven de kosten overblijven of zal dit niet het geval zijn, zodat de bedoelde onvolkomenheid de differentiatie irrationeel maakt.

- Het verwijt, dat men, indien de externe accountant niet geheel van het werk van de interne contrôle zou gebruik maken, tot een doublure zou komen, verwerpt Prof. Dr. S. Kleerekooper mijns inziens terecht. Men moet trachten het maximale verschil te vinden tussen het nuttig effect van de contrôle en de kosten daarvan. Een doublure, die een relatief groot nuttig effect oplevert, is economisch gerechtvaardigd.

Nog één punt dient men bij de beschouwingen over deze materie in het oog te houden: de accountantscontrōle kan geen volledige zekerheid geven, al staat het vast, dat, wanneer het publiek het fiat van de accountant op de jaarrekening vraagt, men volkomen zekerheid omtrent de juistheid van de publicatie verlangt. Prof. Dr. Limperg drukt als volgt uit: ${ }^{15}$ ) ,Evenwel bij nader onderzoek blijkt, dat wij hier toch niet met absolute normen te doen hebben: de geldende normen verwijderen zich altijd min of meer van die vaste basis. In de eerste plaats kan geen mens een volkomen zekerheid verschaffen; het ",menselijk kunnen" schept een eerste grens. Vervolgens eist het rationele handelen, dat het verkeer van de volkomen zekerheid zoveel prijs geeft, dat het resultaat der controble de kosten loont."

Hier wordt dus het economisch principe duidelijk naar voren gebracht.

Tegenover de opvattingen, die de interne contrôle in ieder geval niet willen negeren, staat de opvatting van Dr. Sternheim, dat men dit wel zou moeten doen; deze laatste kan als verouderd worden beschouwd.

De heer H. R. Reder verkondigt in zijn inleiding van 11 Juni 1927 over "De Vaktechnische eisen bij de Contrôle-Arbeid" nog een enigszins andere opvatting: de heer Reder maakt onderscheid tussen de contrôle van de verschillende delen der boekhouding op elkaar - meer interne correlatie dan contrôle - en het contrōleren van de ene functionaris door de andere. Deze laatste soort interne contrōle mag van geen enkele invloed zijn op de contrôle door de openbare accountant.

$B$ ij het op de inleiding volgend debat bleek nog al bezwaar tegen deze stelling te bestaan en ik betwijfel of de heer Reder wel een zo sterk afwijkende mening heeft van het eerste door mij geponeerde standpunt: in zijn repliek heeft hij ergens gezegd: ,Ik geloof nooit, dat men principiëel kan volhouden, dat het geoorloofd zou zijn te steunen op interne contrôle, wanneer het eigen contrôlewerk niet is een sluitstuk, dat op zichzelf binnen omlijnde grenzen zekerheid geeft". In positieve zin omgedraaid, komt dit vrijwel overeen met de eerste stelling.

Beide hiervoor genoemde opvattingen zijn het dus er over eens, dat daar, waar het mogelijk is, voor de openbare accountant door middel van totalen-contrôle en contrôle op critische momenten (hetgeen wat anders is dan mathematische steekproeven) een volledig gesloten contrōle-ring om het bedrijf te leggen, de interne contrôle binnen die ring zinvol is en

15) Prof. Dr. Th. Limperg: „De Functie van den Accountant en de Leer van het Gewekt Vertrouwen" M.A.B. Ocober 1933. 
dat het economisch niet verantwoord is, dat de externe accountant hier de interne contrôle gaat doubleren.

Men kan het probleem, dat in de tegenstelling tussen beide standpunten ligt, als volgt formuleren:

1. Is de openbare accountant bij machte zelfstandig, dit is zonder afhankelijk te zijn van de hulp van de interne contróle, te komen tot een contrôle-systeem, dat hem in staat stelt een certificaat op de jaarrekening af te geven;

2. Zo dit niet het geval is, dan is de methode om de interne contrôledienst te brengen onder de leiding van de openbare accountant een oplossing, waaraan de voorkeur gegeven moet worden boven de methode, om de goede werking van de interne contrôle zonder volledig onderzoek maar alleen door steekproeven na te gaan.

Naar aanleiding van het eerste punt merk ik op, dat naar mijn mening er inderdaad bedrijven zijn, waar de openbare accountant zonder te steunen op de hulp van de interne contrôle, niet tot een bevredigende mate van zekerheid kan komen. Als bekend voorbeeld van deze soort bedrijven gelden de banken, waar, door het incidenteel karakter der transacties en de aard der goederen, een sluitende verbandcontrôle ontbreekt. De moeilijkheden in dit geval vindt men besproken in de reeds hiervoor genoemde lectorale les van Prof. C. A. Blazer "De Contrôle bij Banken” en, meer recent, in een artikel van de heer M. C. Wintersteyn ,De externe contrôle bij banken" M.A.B. April 1946. Doch niet alleen bij banken, ook bij dienstverleningsbedrijven heeft men gevallen, waar soms een verbandcontrôle ontbreekt en een permanente contrōle nodig is. Bij productie- en handelsbedrijven bestaat de mogelijkheid van periodiek uitgevoerde verbandcontrôles, doch de toleranties, die deze contrōles laten, zijn vaak zo ruim, dat de dagelijkse detailcontrôle niet gemist kan worden. Compenserende afwijkingen kunnen bij een contrôle op langere termijn niet ontdekt worden. ${ }^{16}$ ) Dr. A. Mey ${ }^{17}$ ) drukt dezelfde idee als volgt uit: „Wat „ontbreekt aan de vereiste interne contrôle zal men, zoals reeds werd op"gemerkt, door eigen arbeid moeten aanvullen. Ik wijs er echter op, dat .,zodanige aanvulling niet altijd hetzelfde nuttig effect zal hebben, als de ..voorziening van de leemten door verbetering van de organisatie.

"In alle gevallen, waarin de technische contrôle leemten vertoont, is ,aanvulling niet of nauwelijks mogelijk. Zonder een goed functionerende ,technische contrōle heeft de administratieve contrôle geen voldoende „,basis. Zonder voldoende technische contrōle op de efficiëntie van het .gebruik van de arbeidstijd of van het gebruik van materialen en grond„stoffen, kan de accountantscontrôle niet tot een afdoend resultaat komen "omtrent het verband van inkopen van grondstoffen en verkopen van ",product".

Er zijn dus velerlei soort bedrijven, waar een goede interne contrôle voor de openbare accountant onmisbaar is. Ik persoonlijk hecht niet zoveel betekenis aan het gebrek aan technische kennis, dat in dit verband vaak als een tekort van de openbare accountant genoemd wordt. Economisch en administratief is de accountant deskundig: op ander terrein zal hij op het oordeel van anderen moeten afgaan, doch dit is geen "steunen op

16) In dit verband verwijs ik naar de inleiding van den heer J. van Hamersveld: "Enkele Opmerkingen over de Controle bij Grote Bedrijven" 21ste Accountantsdag 1930.

17) Dr. A. Mey: „De Noodzaak van een Nornatieve Theorie der Accountantscontrole als Leiddraad voor de Beroepsuitoefening", "De Accountant" 1936, No. 7 , pagina 236.

m a b blz. 41 
interne contrôle". Bij de contrôle van de jaarrekening gaat het er om, of de resultaten der beheershandelingen op de juiste wijze in die jaarrekening tot uitdrukking komen. Over de zich daarbij voordoende technische vragen heeft de accountant in de meeste gevallen wel een oordeel: zijn deze vragen hem te moeilijk, dan kan hij incidenteel de hulp van deskundigen tot zich trekken.

Aangezien ik dus tot de conclusie gekomen ben, dat de openbare accountant niet altijd bij machte is zonder de hulp van de interne contrōle tot een bevredigend resultaat te komen, moeten wij de tweede vraag nader bezien.

Als wij de interne contrōle overdragen aan de openbare accountant en zijn staf, welke gevolgen heeft dit dan voor de onderneming en voor de accountant?

Om deze vraag te kunnen beantwoorden, wil ik nader ingaan op de staf van de openbare accountant.

Ook wanneer men spreekt over de eigen actie van de openbare accountant, sluit men hierbij in de mogelijkheid, dat de accountant niet alle werk zelf verricht, maar gebruik maakt van assistenten. Artikel 9 van het tot 1947 geldende Reglement van Arbeid zegt: ..Het is de leden geoorloofd de hun opgedragen arbeid onder hun verantwoordelijkheid, mede door hun assistenten, te doen verrichten. Ook op de aldus verrichte arbeid zijn de bepalingen van dit Reglement voor de leden van toepassing". In het nieuwe Reglement is deze bepaling vervallen, zonder dat dit nader gemotiveerd is. Artikel 1 en artikel 3 spreken echter over de werkzaamheden van assistenten en klaarblijkelijk acht men het vanzelfsprekend, dat de accountant zich door assistenten laat bijstaan.

De werkwijze met behulp van assistenten stelt natuurlijk grote eisen aan de organisatie van het accountantskantoor, doch aan de andere kant worden door deze arbeidsverdeling in de contrôle belangrijke economische voordelen bereikt. Wanneer de openbare accountant nu zijn staf zo uitbreidt, dat hij de gehele dagelijkse interne contrôle van de onderneming onder zijn gezag brengt, betekent dit bij ondernemingen van enige omvang, dat een groot aantal assistenten van deze accountant permanent in de onderneming werkzaam zijn. $Z_{i j}$ zijn geheel thuis in alle details van het bedrijf, zijn in dagelijks contact met het personeel van de onderneming en het gevaar dreigt, dat zij zich zo door hun werk en omgeving laten beinvloeden, dat zij zich meer afhankelijk gaan gevoelen van de onderneming, waar zij hun contrôlerende taak verrichten, dan van het accountantskantoor bij hetwelk zij in dienst zijn. Hiertegen dient de externe accountant te waken door zijn personeelsorganisatie zo te maken, dat er een nauwe band blijft bestaan tussen allen, die tot de staf van het accountantskantoor behoren en dat ieder lid hiervan, ook indien het permanent te werk gesteld wordt bij een bepaalde onderneming, zich toch steeds onafhankelijk blijft gevoelen van de leiding van deze onderneming.

Zou men dit niet bereiken, dan is er geen verschil met de interne contrôledienst, die in dienst van de onderneming staat en die natuurlijk ook zo georganiseerd moet worden, dat zij losstaat van de afdelingen, die door haar gecontrôleerd moeten worden.

$E_{r}$ is echter nog een belangrijk nadeel verbonden aan de oplossing om de interne contrỏledienst onder het gezag van de openbare accountant te brengen. Gelijk wij gezien hebben, doet de interne contrôleur werk, dat belangrijk verder gaat dan hetgeen de externe accountant voor zijn contrōleprogramma nodig heeft: hij beweegt zich op gebieden, die geheel 
buiten dat van de openbare accountant liggen: van zijn werkzaamheid hangt, in het geval, dat de contrōle preventief is, de snelheid af, waarmede beheersdaden uitgevoerd kunnen worden. Hij moet op korte termijn aan de bedrijfsleiding gegevens verschaffen, waarop deze beslissingen zal baseren. Kortom, de interne contrôleur vormt een onmisbare schakel in de keten, die een efficiënt bedrijfsbeheer vormt. En uit dien hoofde kan en mag de bedrijfsleiding niet alle zeggingschap over de interne contrōledienst uit handen geven. Zou de externe accountant met zijn staf dit werk overnemen, zouden zijn assistenten naast het algemene contrôlewerk ook directe opdrachten van de bedrijfsleiding gaan uitvoeren en, althans wat de uitvoering van hun werk betreft (ook het contrôlewerk) direct verantwoordelijk worden tegenover de bedrijfsleiding, dan verliest de accountant en zijn staf de onafhankelijkheid tegenover die leiding, die, zoals wij juist gezien hebben, het wezenskenmerk van zijn functie uitmaakt. Dat men bij de grote banken geen externe accountants aantreft, is te verklaren uit het feit, dat de directies der banken er bezwaar tegen hebben de interne contrôledienst geheel onder de leiding van de externe accountant te stellen, welke eis vroeger op grond van de hiervoor gegeven overwegingen, door openbare accountants is gesteld. Ik geloof, dat hierdoor een uit maatschappelijk oogpunt ongewenste toestand is ontstaan.

$\mathrm{lk}$ zie dus niet alleen een practisch, maar ook een theoretisch gevaar in de oplossing om de gehele interne contrōledienst aan de openbare accountant over te dragen. Door verschillende schrijvers ${ }^{18}$ ) wordt dan cok de oplossing hierin gezocht, dat de openbare accountant bij zijn contrôle gebruik maakt van het werk van een interne contrôle-afdeling, geheel losstaande van de beheersafdelingen en onder leiding van een interne accountant, die zijn taak vervult volgens de instructies van de externe accountant; naar mijn mening is deze oplossing ook toe te passen in die gevallen, dat de zelfstandige actie van de accountant het bedrijfsgebeuren niet geheel afdoende omspannen kan. Het feit, dat de interne contrôle onder leiding van een gediplomeerd accountant staat, vormt een waarborg voor de externe accountant, terwijl het ook voor de onderneming de zekerheid geeft, dat de interne contrōle op deskundige wijze geleid wordt. Dat de interne accountant aan het Tuchtrecht onderworpen is, acht ik voor de externe accountant van weinig belang. Het Tuchtrecht is mijns inziens alleen van betekenis voor de verhouding van de accountant tegenover de nietdeskundige buitenwereld. Voor de openbare accountant gaat het er slechts om, of hij de zekerheid heeft, dat de interne contrôleur ook berekend is voor zijn taak.

Vanzelfsprekend moet de openbare accountant maatregelen nemen, dat de interne contrôle goed georganiseerd is en in haar werking effectief. Dit brengt ons terug naar de steekproeven, waarover ik reeds een citaat uit het artikel van Prof. Dr. S. Kleerekooper heb gegeven. Deze steekproeven zijn een doublure, maar geen zinloze. Prof. Dr. Kleerekooper verwerpt de opmerkingen over dit onderwerp in het boek van Dr. L. H. Belle: "Grondslagen der Accountancy", die naar de methode van de mathematische statistiek verwijst. Terecht wijst hij er op, dat fraude, toegelaten door de interne contrôle, door steekproeven onvoldoende ontdekt kan worden. Ook voor het geval, dat men fraude buiten beschouwing laat, kan

18) Zie J. v. Hamersveld: „Enkele Opmerkingen over de Contrōle bij Grote Bedrijven" 21 ste Accountantsdag 1930.

Dr. A. Mey: „De noodzaak van Normatieve Theorie der Accountantscontrole als Leiddraad voor de Beroepsuitoefening" 27ste Accountantsdag 1936.

m a b blz. 13 
de mathematische steekproef niet voldoen, omdat de massa niet homogeen is. Contrôle op critische momenten, in een vast stelsel van contrôles verenigd, kan enige uitkomst bieden daar, waar de totalen-contrôle onmogelijk is of te veel speelruimte laat. Ook deze vorm van contrōle geeft de openbare accountant mathematisch geen volkomen zekerheid. Ik verwijs echter naar mijn opmerking hiervoor gemaakt, dat geen absolute zekerheid verlangd wordt en dat dit standpunt ook gedekt wordt door de Leer van het Gewekte Vertrouwen van Prof. Dr. Limperg, die betoogt, dat het vertrouwen, dat de accountant door zijn arbeid wekt, bepaald wordt door de behoefte van het verkeer en het vermogen der contrōletechniek, om in die behoefte te voorzien: beide factoren, die aan wijzigingen onderhevig zijn. En zo meen ik enerzijds, dat de openbare accountant de behoefte van het verkeer slecht zou verstaan indien hij zich zou terugtrekken uit ondernemingen, waar hij geen tot in details bevredigende volkomen contröle kan uitoefenen en moet steunen op een interne contrôle, wier werking hij niet met absolute zekerheid kan contröleren; en anderzijds, dat, indien de openbare accountant op de bovenbeschreven wijze zijn taak uitvoert, hij hierdoor het gewekte vertrouwen van het publiek niet beschaamt.

Gelijk reeds hiervoor gezegd krijgt de openbare accountant een belangrijke waarborg voor de goede werking van de interne contrỏledienst, indien deze dienst onder leiding staat van een bevoegde interne accountant. Er is dan een collega, van wien men mag aannemen, dat hij voldoende vakbekwaamheid heeft en zijn werk verricht volgens dezelfde vaktechnische en morele normen als de openbare accountant. Deze laatste heeft dus grotere zekerheid, dat de lage contrôleurs hun werk naar behoren verrichten en dus zal hij minder intensief op deze contrôle behoeven toe te zien.

Een zeer belangrijke vraag is, in hoeverre de openbare accountant het gehele contrôlewerk aan zijn interne collega mag overlaten.

Ik heb er hiervoor reeds opgewezen, dat de openbare accountant op dit gebied de leiding heeft en aanwijzingen moet geven. Maar moet men zover gaan als Dr. Mey in zijn hiervoorgenoemde inleiding, die zegt, dat de samenwerking moet zijn als tussen de senior partner en de verantwoordelijke medewerker op het accountantskantoor? Wanneer men omtrent deze samenwerking leest wat in het nieuwe Reglement van Arbeid staat, vindt men het volgende: In artikel 4 laatste lid wordt aan de leden van het N.I.V.A., die hun praktijk uitoefenen met bijstand van of in samenwerking met een ander lid als medewerker, dezelfde verplichtingen opgelegd ten aanzien van de arbeid en mededelingen van die medewerker, als geldt ten aanzien van een medefirmant: deze verplichtingen vindt men in het eerste en tweede lid van artikel 4 luidende: ,Een lid, dat de praktijk ,uitoefent in maatschap met een ander lid, is verplicht zodanige voorzie,ningen te treffen, dat hij zich in redelijkheid overtuigd kan houden, dat de , arbeid van zijn mede-vennoot en diens mededelingen omtrent de uit„,komsten van onderzoekingen voldoen aan de bepalingen van dit regle,ment. Deze verplichting strekt zich niet verder uit dan de algemene ..grondslagen van de onderzoekingen.

" Onder algemene grondslagen van de onderzoekingen worden verstaan ,zowel de algemene beginselen, vastgesteld in de reglementen van het ..Nederlandsch Instituut van Accountants als de beginselen, volgens ,welke de werkprogramma's voor de onderzoekingen van de maatschap .,worden opgesteld."

m a b blz. 44 
Wanneer deze wijze van samenwerken als basis zou gelden voor de verhouding tussen de openbare en de interne accountant, zou de zelfstandige taak van de openbare accountant verdwijnen en hij alleen een zeer globale supervisie over het werkprogramma behouden.

Ik geloof ook niet, dat Dr. A. Mey werkelijk zo ver wil gaan en dat hij in de praktijk zal vasthouden aan een minimum inhoud voor de contrôle van de openbare accountant, die het karakter moet behouden van een in grote totalen uitgevoerde volkomen contrôle. In dit verband heeft Dr. Mey verwezen naar de minimum eisen van de heer Reder, en heeft hij deze zelf nader uitgewerkt. Het mijns inziens tot verwarring aanleiding gevende woord ,medewerker" voor de interne accountant heeft Dr. Mey waarschijnlijk gekozen om duidelijk tot uitdrukking te brengen, dat de interne accountant werktechnisch geincorporeerd is in de organisatie van de openbare accountant.

Een enigszins andere opvatting vindt men bij de heer Goudeket. In zijn hiervoor genoemde referaat ${ }^{19}$ ) gaat hij uit van de gedachte, dat de interne accountant van zijn directie opdracht tot volledige contrôle ontving en meent, dat de externe accountant volledig op de contrôle van de interne collega kan vertrouwen en er zich toe kan bepalen door steekproeven vast te stellen, dat het vertrouwen gerechtvaardigd is. Hoe hij zich dit denkt, blijkt het best uit het volgende citaat:

„Ik kan niet beter doen dan hier den heer van Hamersveld te citeren, „,waar hij in zijn inleiding voor de Accountantsdag 1930 een opsomming .,geeft der werkzaamheden van de externe contrôledienst. Uitdrukkelijk ,heb ik hierbij twee der door den heer van Hamersveld genoemde punten ,weggelaten, namelijk de organisatie van de interne contrôledienst en ., het overleg inzake de werkprogramma's.

.,Ik citeer:

„De interne contrōledienst zal aan het beheer en aan den public-accoun,tant regelmatig verslag uitbrengen van zijn arbeid en alle mededelingen ,van de foutenberichtgevingsdienst zullen hem moeten worden doorge.,geven, opdat hij weet, waar en door wien gefaald is en welke maatregelen .genomen zijn om de gerapporteerde fouten in de toekomst te doen ver,,mijden.

„De desbetreffende contrôle-dossiers moeten door hem worden door.,gewerkt en de rapporten, welke op grond daarvan aan het beheer worden ,uitgebracht, moeten door hem worden bestudeerd.

.Hij zal verder regelmatig onderzoekingen doen ter contrôle van de .,effectiviteit der interne contrōle en voor het verzamelen van die gege.,vens, welke hij, onafhankelijk van anderen, wenst te ontvangen (onder ,,andere ten opzichte van de verhouding tussen moedermaatschappij, fili,.alen en onder-ondernemingen en van de zwevende posten).

„Hij zal door zelfstandige verwerking en combinatie gedurende de .,loop van het boekjaar, van de tegelijkertijd aan het beheer en aan hem ,ter hand gestelde, gewaarmerkte boekingsstaten en verantwoordingen .,der interne contrôleafdeling de nodige bouwstoffen verzamelen om regel,,matig de ontwikkeling der cijfers te kunnen volgen, teneinde, na afloop .,van het boekjaar, de gegevens voor het opstellen der jaarrekening in ",eigen bezit te hebben."

Bij het debat, dat de inleiding van de heer Goudeket heeft uitgelokt, is

19) M.A.B. Jan. ' 49 blz. 6. 
gewezen op het onjuiste gebruik van steekproeven om de goede taakvervulling van de interne accountant na te gaan. Ook ik acht steekproeven tegenover een collega niet juist in tegenstelling tot het geval, dat de interne contrōle niet onder leiding van een bevoegd accountant staat: er moet toezicht zijn en leiding door de openbare accountant, in de vorm, zoals dit door den heer van Hamersveld is gesteld. Hij zal - en dit in afwijking van de mening van de heer Groudeket - ook moeten nagaan, dat de interne contrôle-organisatie doeltreffend is opgezet en hij zal de werkprogramma's en instructies voor het personeel moeten goedkeuren, voor zover deze voor zijn contrôle van belang zijn: of dit het geval is, dient hij en hij alleen te beoordelen.

Gelijk ik hiervoor reeds uitdrukkelijk betoogd heb, heeft de externe accountant, waar het werkzaamheden ten behoeve van de contröle op de jaarrekening betreft, de hogere verantwoordelijkheid en geeft hij dus, bij meningsverschil met de interne accountant de doorslag. Welke werkzaamheden hij als minimum programma voor zichzelf zal reserveren, is niet in abstracto te zeggen en hangt af van de aard van de onderneming. de organisatie en de graad van administratieve perfectie. Een in totalen uitgevoerde contrôle van het gehele bedrijfsgebeuren zou ik als minimum eis voor de openbare accountant handhaven: wanneer echter in de administratie een systeem van budgettering is verwerkt, wordt hierin een taakstellend en normgevend element gevonden, dat de accountantscontröle sterk kan vereenvoudigen: hetzelfde geldt, indien de onderneming over rijk statistisch materiaal beschikt: de accountantscontrôle kan dan soms tot een cijferbeoordeling teruggebracht worden. De balanscontrôle behoort principieel tot het terrein van de openbare accountant, evenals de wijze van verslaglegging van het gevoerde beheer in de jaarstukken: maar controle op de aanwezigheid van bepaalde activa, bijvoorbeeld voorraden, kan hij, naar mijn mening, vanzelfsprekend onder zijn verantwoordelijkheid overdragen aan de interne accountant. Ik hoop met deze enkele aanwijzingen mijn opvatting voldoende duidelijk gemaakt te hebben. ${ }^{20}$ )

Het is nog van belang te wijzen op het artikel van de heer G. P. J. Hogeweg in het M.A.B. 1947 No. 4, waarin hij mijn lectorale les bespreekt. Hierbij erkent de heer Hogeweg, dat artikel 7 lid 2 van het nieuwe Reglement van Arbeid het mogelijk maakt van de verklaring van een interne accountant gebruik te maken, mits hij er maar voor zorgt ,,door eigen aanvullend onderzoek een zodanige grondslag voor zijn verklaring te leggen, dat zijn arbeid blijft voldoen aan het tweede lid van artikel 2". De heer Hogeweg acht deze bepaling limitatief en meent dat verklaringen van een interne contrôleur, niet lid van een erkende accountantsvereniging, door de externe accountant niet gebruikt mogen worden en acht op die grond het inschakelen van de interne contrôle in het contrôleplan van de public accountant niet toelaatbaar.

Ik kan deze opvatting niet delen. Bij artikel 7 Reglement van Arbeid moet men speciale nadruk leggen op het feit, dat het handelt over het gebruik van een verklaring, en niet over het inschakelen van anderen bij het contrôlewerk. De verklaring van de interne accountant mag niet zonder meer geaccepteerd worden, in tegenstelling tot de verklaring van de public-accountant. In dit verband is het interessant pagina 16 van het

20) Voor de werkzaamheden van de interne accountant bij de banken verwijs ik naar het reeds genoemde artikel van de Heer M. C. Wintersteyn, M.A.B. April 1946. Verder geven de hiervoor genoemde artikelen van P. M. Rees en V. H. Stempf bijzonderheden omtrent het werk, dat men door de interne accountant wil laten verrichten.

m a b blz. 46 
Nader Rapport van de Commissie tot herziening van het Reglement van Arbeid van 1942 te herlezen, waar geantwoord wordt op de opmerking van Drs de Lange, dat men in artikel 8 van het ontwerp (tegenwoordig artikel 7) een voorkeur zou kunnen zien voor de vreemde collega boven de associe en waar de commissie er op wijst, dat het in dit artikel niet gaat over de appreciatie van het werk, doch uitsluitend over de afgegeven verklaring.

De heer Hogeweg erkent niet mijn stelling, dat er slechts gradueel verschil is tussen de interne contrōleur en de interne accountant.

\section{Eisen te stellen aan de taakvervulling door de interne accountant.}

In het hierna volgende wil ik enige beschouwingen wijden aan de vraag. welke invloed de opdrachtgever, die in dit geval meestal tegelijk de werkgever is, kan uitoefenen op de taakvervulling door de interne accountant en voorts, welke verplichtingen, door Statuten en reglementen van het N.I.V.A. gesteld, door de interne accountant bij de uitvoering van zijn arbeid moeten worden nagekomen.

Wat betreft de openbare accountant bestaat over deze onderwerpen een uitvoerige litteratuur: voor zover mij bekend, is deze materie nooit behandeld vanuit het standpunt van de interne accountant. Bij de interne accountant kan men, evenals bij de openbare accountant, spreken van een adviserende en een contrôlerende functie. Wanneer wij alleen deze laatste nader bezien, geloof $i k$, dat in het algemeen de eis gesteld mag worden, dat, als de interne accountant ingeschakeld wordt in de contröle van de onderneming, hij geen beperkingen in het contrôleterrein krijgt, anders dan die, welke in overleg met de externe accountant, met wie hij moet samenwerken, worden aangebracht, doordat deze laatste bepaalde werkzaamheden voor de contrôle van de jaarrekening voor zichzelve reserveert en een doublure hiervan zoveel mogelijk vermeden moet worden. Het werk van een interne accountant moet zinvol zijn: een fragmentarische contrôle van bepaalde onderdelen van de administratie is dit niet. Prof. Dr. Limperg zegt in zijn M.A.B. artikel ${ }^{21}$ ) naar aanleiding van de openbare accountant, wiens arbeid uitsluitend bestemd is voor een beperkte kring, dus in de private taak of het gesloten verkeer werkzaam is:

„Ook voor de functie van de contrōleur in het gesloten verkeer kan ,en moet de eis worden gesteld, dat zij een rationele functie zij; ook zij „,kan niet willekeurig worden ingekort, zonder al spoedig ineen te schrom.,pelen tot iets ondoelmatigs en zinledigs. Ook in het gesloten verkeer "leidt de irrationele functie er onvermijdelijk toe, dat de accountant door ,de aanvaarding dier functie een groter vertrouwen opwekt dan hij door ,,zijn arbeid kan rechtvaardigen; ook in de kleine kring kan niemand ver,wachten, dat de accountant een functie aanvaardt, welke vervulling hij .,als vakman niet doeltreffend acht."

Ik zou deze woorden, ofschoon niet daarvoor bedoeld, volledig willen toepassen op de interne accountant: ook hij kan zich als vakman, door $z$ ijn opdrachtgever niet iedere willekeurige beperking in zijn taakvervulling laten welgevallen: de gezagsverhouding, waarin hij tot deze opdrachtgever staat, heeft hierop geen invloed.

Men heeft de hierboven aangehaalde woorden van Prof. Dr. Limperg verbonden aan de eis, dat de contrôle volkomen moet zijn; dit is: een sluitend geheel vormen, doeltreffend voor de vervulling van de functie. Nu is

21) t.a.p. M.A.B. November 1933. 
de functie van de interne accountant een andere dan van de openbare accountant en behoeft men voor de interne accountant het begrip ,,volkomen contrôle" zeker niet zo uit te leggen als het voor zijn externe collega vaak gebeurt, namelijk in de zin, dat zijn contrôle in ieder geval het gehele bedrijfsgebeuren moet omspannen. Stelt men deze eis echter wel, dan komt men in grote moeilijkheden door het Reglement van Arbeid. Dit eist immers in artikel $112 \mathrm{e}$ lid een ",voorbehoud" in iedere verklaring als het onderzoek niet volkomen geweest is, terwijl artikel 12 de eis stelt, dat het voorbehoud aan de strekking van de verklaring niet wezenlijk afbreuk mag doen. De heer Goudeket ${ }^{22}$ ) acht voor de interne accountant de volledige contrōle - althans bij industriële bedrijven - de enige rationele. Hij drukt zich als volgt uit: „Ik kan me daar moeilijk voorstellen, dat de ,interne accountant een andere dan een volledige opdracht zou krijgen. "Ik zou niet weten, wil men nog van een zelfstandige contrôle spreken, "welke onderdelen niet onder de contrōle van de interne accountant „,zouden vallen." Men zou zich natuurlijk kunnen redden door als interne accountant geen verklaringen af te geven, doch daar artikel 13 Reglement van Arbeid ook voor de interne accountant geldt, is ieder stuk, dat zijn naam vermeldt reeds als een verklaring te beschouwen.

Persoonlijk geloof ik, dat men voor bepaalde groepen accountants en wel de interne accountants en de ambtenaren-accountants de eis van de volkomenheid der contrōle zo moet opvatten, dat de uitgevoerde contrōle voor het gestelde doel rationeel is. Ook voor de openbare accountant in "private taak" zou ik niet verder willen gaan, doch dit punt laat ik verder buiten beschouwing. $\mathrm{lk}$ kan mij dus zeer goed voorstellen, dat de contrôle van de interne accountant zich beperkt tot bepaalde afgeronde delen van de administratie. Over deze materie, gezien van het standpunt van de rijksaccountant, is een interessante discussie te vinden in M.A.B. Juni 1940 van de heren W. N. de Blaey, J. Delmonte, J. H. Hageman en J. L. van der Pauw naar aanleiding van een artikel van D. Nye in M.A.B. December 1939 over ..Enige opmerkingen over de onderzoeken door Rijksaccountants ten behoeve van de belastingadministratie". Het probleem ligt daar echter geheel anders dan bij de interne accountant. De accountant-ambtenaar zal zijn contrōle zoveel mogelijk in totalen uitvoeren en eventueel tot cijferbeoordeling beperken. De interne accountant zal juist de details contrōleren en misschien het beoordelingswerk, de materiële contrôle aan de externe accountant overlaten. De verhouding, zoals die bestaat tussen interne en openbare accountant vindt men dan ook enigszins getransponeerd in de verhouding ambtenaar-accountant en openbare accountant, met dien verstande, dat in dat geval de positie van de laatste te vergelijken is met de interne accountant.

Uit het verslag van de algemene vergadering van het N.I.V.A. van 22 Juni 1946 (,.De Accountant" September 1946) meen ik te mogen opmaken, dat ook Prof. Dr. Limperg met mijn opvatting van de "volkomen" contröle kan meegaan. Op pagina 89 zegt hij, dat onder een volkomen contrôle verstaan moet worden een contrôle, die volkomen is binnen het kader van het doel, .,dat aan de onderzoekingen ten grondslag ligt."

Welke eisen stellen nu Statuten en Reglementen van het N.I.V.A. aan de taakvervulling door de interne accountant? Ik kan mij vergissen, maar ik meen, dat deze in het geheel niet over de interne accountant spreken. Dat betekent dus, dat het Reglement van Arbeid ook geldt voor de in-

22) A. Goudeket: „De Interne Accountant”, De Accountant 1939, No. 9 pagina 326.

m a b blz. 48 
terne accountant. Bij de openbare behandeling van het voorstel voor een nieuw Reglement van Arbeid in 1939 is deze vraag wel ter sprake gekomen, zij het dan, dat speciaal over de accountant in Overheidsdienst werd gesproken. In het Nader Rapport van de Commissie van 1942 schreef deze hierover het volgende:

.De tweede vraag van algemene aard is: moet het Reglement ook van "toepassing zijn op accountants in dienstbetrekking buiten het vrije be",roep, meer in het bijzonder op accountants in Overheidsdienst."

„De Commissie is van mening, dat de reglementen van het Instituut "geen onderscheid mogen maken in de plichten van hen, die het beroep ,van accountant uitoefenen.

.Wat de accountants in particuliere dienst betreft, mag dit niet, omdat ,de contrôle-arbeid ook in dienstbetrekking veelal verantwoordelijkheid ,,schept, welke van dezelfde aard is als die van den accountant in het vrije „,beroep. Ook voor de accountants in Overheidsdienst acht de Commissie "geen uitzonderingspositie nodig."

Deze laatste groep heeft bij monde van een groot aantal vooraanstaande Rijksaccountants bezwaren aangetekend tegen het feit, dat in het Ontwerp-Reglement van Arbeid 1939 met hun positie onvoldoende rekening was gehouden. Van de kant van de interne accountants zijn geen goed- of afkeuringen vernomen: toch meen ik, dat hun bijzondere positie tegenover hun werkgever de mogelijkheid van conflicten met het Reglement van Arbeid niet uitsluit. I $k$ denk in dit verband bijvoorbeeld aan artikel 2, waaruit blijkt volgens de toelichting, dat de geheimhoudingsplicht ook geldt tegenover de opdrachtgever, voor zover aangaat feiten en omstandigheden, waaromtrent de kennis in het verband van het doel van het vereiste onderzoek voor de opdrachtgever niet is vereist. En zo zijn er misschien nog wel enige bepalingen, die de interne accountants voor moeilijkheden kunnen brengen. Deze uiteenzetting heeft mij gebracht tot het laatste onderwerp, dat ik wilde bespreken, namelijk de positie van de interne accountant in het N.I.V.A.

\section{De positie van de interne accountant in het Nederlandsch Instituut van Accountants.}

Gelijk ik bij de aanvang van dit artikel reeds mededeelde, ontbreekt een juist inzicht in het totaal aantal leden, dat als interne accountant in het particuliere bedrijfsleven werkzaam is. Toch is het aantal niet gering en waarschijnlijk nog steeds stijgend.

De vraag moet nu gesteld worden hoe de positie van deze groep leden is in het Instituut. Hiertoe moeten wij het karakter van het N.I.V.A. nagaan. Men heeft zich altijd tot doel gesteld alle accountants - dus zij. die krachtens hun opleiding als volwaardige accountants beschouwd kunnen worden - in één vereniging samen te binden. Men heeft, om hier in te slagen, wel enige concessies moeten doen, zoals blijkt uit de gedifferentiëerde contributieregeling, waardoor eigenlijk al een splitsing in het Instituut gekomen is. Officiëel heeft men het begrip accountant als functie buiten beschouwing gelaten en nergens vindt men in statuten of reglementen dan ook aanwijzing, dat er naar hun functie verschillende groepen zijn, zoals ambtenaar-accountant, openbare accountant en interne accountant. De grootste en oudste groep der openbare accountants heeft echter wel zeer sterk zijn stempel gedrukt op deze statuten en reglementen en ik acht het te betreuren, dat men tot nu toe zo weinig aandacht besteed heeft aan de vraag of het Instituut moet zijn een beroepsvereniging 
of een vereniging van personen, die eenzelfde opleiding genoten en een bepaalde wetenschappelijke graad bereikt hebben, doch in geheel verschillende beroepen werkzaam kunnen zijn. Ook het gehele ontwerp tot regeling van het accountantswezen van 1939 lijdt aan deze tweeslachtigheid. Ofschoon kennelijk bedoeld het beroep te regelen, laat het de mogelijkheid vrij, dat in het register personen worden ingeschreven, die het beroep niet uitoefenen. Voor de openbare accountant is het Nederlandsch Instituut van Accountants een beroepsvereniging: statuten en reglementen houden zich uitvoerig met de beroepsuitoefening bezig, echter zonder uitdrukkelijk te stellen, dat deze regelen alleen gelden voor de openbare accountant. Dit geeft het bezwaar, dat deze regelen nu ook gelden voor die leden, die niet het beroep van zelfstandig gevestigd openbaar accountant uitoefenen en wier beroep andere eisen stelt. Voor de accountantambtenaar geldt deze moeilijkheid wel zeer sterk: in het voorgaande hoofdstuk wees ik reeds op enige gevallen, waarin stemmen van accountants-ambtenaren hierop gewezen hebben. Het nieuwe Reglement van Arbeid heeft deze moeilijkheden niet opgeheven. Het Wetsontwerp 1939 heft in artikel 27 lid 3 de bepalingen van de Tuchtrechtspraak voor de accountants in openbare dienst op, hetgeen van zeer ingrijpende betekenis is. Reeds herhaaldelijk is de vraag gesteld of de accountants-ambtenaren een plaats in het Instituut hebben of dat zij beter doen zich afzonderlijk te organiseren. Het laatst is hierover een artikel verschenen van de heer W. N. de Blaey "Ordening van het Accountantsberoep in Nederland" in M.A.B. Februari 1946: deze bepleit éen vereniging met twee secties: een voor publieke accountant en een voor overheidsaccountants. Als doel van de vereniging is zeer speciaal gedacht de regeling van het beroep. De vraag kan nu gesteld worden of ook voor de groep van de accountants, in dienst van het particuliere bedrijfsleven, niet een afzonderlijke sectie moet worden gevormd. Ik wijs er in dit verband op, dat in Amerika sinds 1941 het "Institute of Internal Auditors" bestaat. Het ingewikkelder worden van het economische leven dringt in de richting van specialisatie en het is mogelijk, dat in de toekomst ook de interne accountants bij ons de behoefte zullen gevoelen, dat de met hun specifieke beroepsuitoefening samenhangende vraagstukken meer tot hun recht zullen komen dan tot nu toe in het N.I.V.A. geschied is. Persoonlijk geloof ik dit niet. De werkzaamheden van de interne accountant zijn niet zo zeer verschillend van die van de openbare accountant, wat het bedrijfseconomisch en het contrôletechnisch gebied betreft, dat men hiervoor een splitsing behoeft te maken. Wel meen ik, dat men zich meer dan te voren, bij het maken van reglementen voor de leden van het N.I.V.A. zal moeten realiseren, welke bepalingen uitsluitend bestemd zijn voor die leden, die in de openbare beroepsuitoefening werkzaam zijn en waaraan zeer speciale eisen gesteld moeten worden. De interne accountants zouden toch hun plaats in het Instituut kunnen houden en onder de algemene bepalingen vallen.

Op deze wijze zouden allen, die de accountantsstand vormen, in één verband blijven en dit heeft het grote voordeel, dat de verschillende groepen in onderling contact zeer bevruchtend op elkaar kunnen inwerken.

De groep van de interne accountants is relatief nog bescheiden, maar zij is groeiende. De interne accountant heeft naar mijn stellige overtuiging een eigen en zeer belangrijke taak in het economische leven. Ik vertrouw. dat deze groep ook haar eigen plaats in het Nederlandsch Instituut van Accountants zal weten te vinden en tot de bloei van het Instituut zal bijdragen.

m a b blz. 50 